Buletin Ilmiah Math. Stat. dan Terapannya (Bimaster)

Volume 08, No. 3 (2019), hal 379 - 386.

\title{
PENENTUAN CADANGAN PREMI ASURANSI JIWA DWIGUNA MENGGUNAKAN METODE FULL PRELIMINARY TERM DAN PREMIUM SUFFICIENCY
}

\author{
Lia Amelia Tarigas, Neva Satyahadewi, Hendra Perdana
}

\begin{abstract}
INTISARI
Cadangan premi merupakan besarnya uang yang ada pada perusahaan dalam jangka waktu pertanggungan sebagai persiapan pembayaran klaim. Cadangan premi tersebut berasal dari selisih nilai tunai premi dan nilai uang pertanggungan. Dalam kenyataanya perusahaan asuransi memerlukan biaya, seperti biaya agen, penutupan polis, pajak dan lain sebagainya. Metode cadangan premi full preliminary term dan premium sufficiency merupakan metode yang menyertakan biaya operasional dalam perhitungannya. Data yang digunakan pada penelitian ini adalah data pada Tabel Mortalita Indonesia 2011 untuk seorang pria berusia 30 tahun, lama masa pertanggungan 25 tahun, tingkat suku bunga $3 \%$. Santunan yang diterima Rp150.000.000,-, biaya penutupan polis baru 2,5\% dari santunan dan biaya pemeliharaan premi setelah masa pembayaran 0,13\% dari santunan. Perhitungan menggunakan metode cadangan full preliminary term dan premium sufficiency diperoleh bahwa nilai cadangan full preliminary term lebih murah dibandingkan nilai cadangan premium sufficiency. Hal ini dikarenakan premi pada tahun pertama pada full preliminary term digunakan untuk menutupi biaya loading sehingga nilai cadangan lebih murah. Perhitungan dengan menggunakan suku bunga bervariasi, diperoleh bahwa nilai cadangan premi akan semakin murah seiring dengan bertambahnya tingkat suku bunga yang digunakan.
\end{abstract}

Kata Kunci: full preliminary term, premium sufficiency

\section{PENDAHULUAN}

Manusia tidak ada yang dapat mengetahui segala kemungkinan yang akan terjadi di kehidupan yang akan datang, misalnya kematian, kecelakaan, kerugian, bencana alam dan lain-lain. Oleh karena itu, sebuah perlindungan tentu dibutuhkan oleh setiap orang, baik untuk melindungi diri sendiri, keluarga, maupun harta benda. Kehadiran industri asuransi pada saat sekarang ini merupakan hal yang sangat penting. Seseorang yang mengikut sertakan diri dalam asuransi dapat memperkecil risiko yang ada dalam kehidupan sehari-hari. Asuransi pada dasarnya adalah sebuah tindakan, sistem atau bisnis dimana terdapat perjanjian antara kedua belah pihak dalam hal perlindungan. Salah satu jenis asuransi adalah asuransi jiwa.

Asuransi jiwa dapat didefinisikan sebagai suatu upaya perlindungan yang diberikan oleh pihak penanggung terhadap risiko pada jiwa tertanggung dalam bentuk perjanjian (polis asuransi) [1]. Pihak tertanggung membayarkan kewajiban (premi) kepada penanggung sebagai imbalan persetujuan penanggung untuk membayar jumlah tertentu jika tertanggung meninggal dunia. Asuransi jiwa dibagi menjadi tiga jenis, yaitu asuransi jiwa berjangka, asuransi jiwa seumur hidup, dan asuransi jiwa dwiguna (endowment). Asuransi jiwa dwiguna memberikan dua manfaat yaitu bila tertanggung meninggal sebelum waktu tempo maka ahli waris akan menerima manfaat premi dan bila tertanggung masih hidup setelah waktu tempo maka tertanggung akan memperoleh manfaat premi. Asuransi jiwa dwiguna merupakan perpaduan antara asuransi jiwa berjangka dan asuransi jiwa dwiguna murni [2].

Pada asuransi jiwa, besarnya santunan tergantung atas premi. Premi merupakan sejumlah uang yang wajib dibayarkan oleh tertanggung kepada penanggung yang besarnya sudah ditentukan. Pembayaran santunan kepada tertanggung atau pemegang polis saat terjadi klaim, perusahaan asuransi atau penanggung harus mempunyai dana dari premi yang dibayarkan tertanggung. Rangkaian pembayaran atau penerimaan dana tetap dalam jumlah tertentu yang dilakukan secara berkala pada jangka waktu tertentu disebut dengan anuitas [1]. Iuran atau premi yang diterima perusahaan tidak hanya menjadi 
profit perusahaan tetapi sebagian juga merupakan kewajiban perusahaan di masa mendatang.Kematian seseorang bisa datang sewaktu-waktu begitu juga dengan kematian seorang pemegang polis. Dengan begitu perusahaan asuransi juga dapat mengeluarkan sejumlah uang sewaktu-waktu jika ada salah satu pemegang polis asuransinya yang meninggal. Perusahaan asuransi bisa saja mengalami kerugian ketika ada pemegang polis yang meninggal, sementara perusahaan asuransi tidak mempunyai dana, padahal harus mengeluarkan sejumlah dana untuk manfaat. Jika tertanggung sudah membayarkan preminya maka kewajiban dari perusahaan asuransi adalah menyiapkan cadangan untuk memenuhi uang pertanggungan ketika terjadi klaim.

Cadangan premi merupakan besarnya uang yang ada pada perusahaan dalam jangka waktu pertanggungan. Cadangan premi tersebut berasal dari selisih nilai tunai premi dan nilai uang pertanggungan [1]. Perhitungan cadangan premi tersebut dilakukan melalui metode perhitungan matematika aktuaria, yaitu menggunakan metode prospektif dan retrospektif. Perhitungan dengan metode prospektif maupun retrospektif menggunakan premi bersih (netto) sebagai dasar pehitungannya. Dalam kenyataannya perusahaan asuransi memerlukan biaya, seperti biaya komisi agen, penutupan polis, pajak dan lain sebagainya. Perusahaan asuransi dalam menghindari kerugian, terutama ditahun-tahun awal maka metode cadangan prospektif maupun retrospektif perlu dikembangkan dengan menyertakan biaya-biaya operasional dalam perhitungannya.

Penelitian ini mengkaji beberapa model dalam metode cadangan premi asuransi, yaitu metode full preliminary term dan premium sufficiency. Kedua metode tersebut merupakan perluasan dari metode prospektif dengan menyertakan biaya operasional perusahaan dalam perhitungan nilai cadangan. Penelitian ini bertujuan untuk mengkaji cadangan premi dengan menggunakan metode full preliminary term dan premium sufficiency dan diberikan aplikasi numerik pada asuransi jiwa dwiguna. Tingkat suku bunga yang akan digunakan yaitu 3\%, mengunakan Tabel Mortalita Indonesia (TMI) 2011.

Penentuan cadangan full preliminary term dan premium sufficiency dimulai dari menentukan usia tertanggung $(x)$ tahun, lama masa pertanggungan $(n)$, biaya penutupan baru $\left(a^{\prime}\right)$, biaya pemeliharan premi setelah masa pembayaran $\left(\gamma^{\prime}\right)$, dan besar santunan yang dipilih $(B)$. Selanjutnya, menghitung nilai asuransi, menghitung nilai anuitas dan menghitung nilai premi tahunan untuk produk asuransi jiwa dwiguna. Setelah itu, ditentukanlah nilai cadangan premi metode full preliminary term dan premium sufficiency dari sebuah perusahaan.

\section{TABEL MORTALITA}

Tabel Mortalita berasal dari PAI ( Persatuan Aktuaris Indonesia), dengan melakukan observasi pada suatu kelompok, masing-masing anggota diobservasi mengenai tingkat kematiannya berdasarkan kelompok umur [1]. Dimisalkan $d_{x}$ ialah jumlah orang yang meninggal dari $l_{x}$ orang sebelum usianya beranjak $x+1$ tahun maka jumlah orang akan tetap hidup hingga usia $x+1$ tahun dapat dinyatakan dengan:

$$
l_{x+1}=l_{x}-d_{x}
$$

Bagian terpenting pada tabel mortalita ialah kolom $\left(q_{x}\right)$, karena bilangan yang ada pada kolom ini diperkirakan dari data yang telah dikumpulkan oleh pihak asuransi jiwa sebelumnya [3]. Peluang meninggal $k$ dalam asuransi bisa disimbolkan dengan ${ }_{n} q_{x}$ yang diartikan sebagai peluang meninggalnya seseorang pada usia $x$ dalam $n$ tahun maupun sebelum usianya $x+n$ dapat dituliskan dengan:

$$
\begin{aligned}
{ }_{n} q_{x} & =1-{ }_{n} p_{x} \\
& =\frac{d_{x}}{l_{x}}
\end{aligned}
$$


Dikarenakan jumlah peluang hidup dan meninggal seseorang ialah 1, maka diperoleh hubungan antara kemungkinan hidup dan kemungkinan meninggal:

$$
\begin{aligned}
q_{x}+p_{x} & =1 \\
p_{x} & =1-q_{x}
\end{aligned}
$$

Peluang hidup seseorang berusia $x$ akan hidup 1 tahun kemudian dinotasikan dengan $p_{x}$ sedangkan ${ }_{n} p_{x}$ dan diartikan sebagai peluang seseorang yang berusia $x$ tahun akan hidup dalam waktu $n$ tahun.

$$
{ }_{n} p_{x}=\frac{l_{x+n}}{l_{x}}
$$

\section{TINGKAT SUKU BUNGA}

Tingkat suku bunga (i) adalah rasio dari besar bunga yang diperoleh selama periode tertentu terhadap besarnya nilai pokok pada saat awal periode [4]. Nilai sekarang adalah investasi sebesar 1 yang akan terakumulasi menjadi $(i+1)$ pada akhir periode ke 1 [1]. Nilai sekarang pada periode $n$ juga bisa disebut dengan faktor diskonto yang dinotasikan dengan $v^{n}$, yaitu:

$$
v^{n}=\frac{1}{(i+1)^{n}}
$$

\section{ASURANSI JIWA DWIGUNA}

Asuransi jiwa dwiguna $n$ tahun $\left(A_{x: n}\right)$ dapat dipandang sebagai kombinasi dari asuransi jiwa berjangka $n$ tahun $\left(A_{x: n}\right)$ dan asuransi jiwa dwiguna murni $n$ tahun $\left(A_{x: n}\right)$. Oleh karena itu, pada asuransi dwiguna manfaat kematian akan diberikan apabila tertanggung (insured) meninggal sebelum $n$ tahun. Sebaliknya, apabila tertanggung (insured) masih hidup sampai dengan $n$ tahun maka kepadanya akan diberikan dwiguna murni. Nilai sekarang aktuaria (actuarial present value) untuk asuransi jiwa dwiguna sebagai berikut:

$$
\begin{aligned}
A_{x: n} & =A_{x: n}+A_{x: n} \\
& =\left(\sum_{k=0}^{n-1} v^{k+1}{ }_{k} p_{x} q_{x+k}\right)+v^{n}{ }_{n} p_{x}
\end{aligned}
$$

dimana:

$n \quad=$ lama masa periode pertanggungan asuransi

$k \quad=$ sisa masa pertanggungan asuransi

$v^{k+1} \quad=$ faktor diskonto periode $(k+1)$

${ }_{k} p_{x} \quad=$ peluang seseorang berusia $x$ tahun akan hidup sampai $k$ tahun

$q_{x+k} \quad=$ peluang seseorang berusia $(x+k)$ tahun akan meninggal

$v^{n} \quad=$ faktor diskonto pada periode $n$ tahun

${ }_{n} p_{x} \quad=$ peluang seseorang berusia $x$ tahun akan hidup sampai $n$ tahun

\section{ANUITAS JIWA}

Anuitas adalah suatu deretan pembayaran, biasanya dalam jumlah yang sama untuk suatu jangka waktu dan lama tertentu secara berkelanjutan. Anuitas jiwa adalah anuitas yang setiap pembayarannya hanya dilakukan jika pemegang polis masih hidup atau dalam jangka waktu yang ditentukan sesuai dengan jenis kontrak asuransinya. Teori anuitas memegang peran penting dalam aktuaria, karena pembayaran premi kepada perusahaan asuransi jiwa oleh pemegang polis mempunyai bentuk anuitas 
jiwa pemegang polis kepada perusahaan [5]. Pada penelitian ini anuitas jiwa yang digunakan dalam perhitungan yaitu anuitas jiwa disket awal berjangka $n$ tahun. Rumus anuitas jiwa ini yaitu:

$$
\ddot{a}_{x: n}=\sum_{k=0}^{n-1} v^{k}{ }_{k} p_{x}
$$

\section{PREMI}

Premi adalah sejumlah uang yang dibayarkan oleh tertanggung kepada penangggung yang besarnya sudah ditentukan. Secara umum terdapat dua jenis premi, yaitu premi bersih (netto) dan premi kotor (bruto). Premi netto adalah premi yang perhitungannya hanya menggunakan perkiraan tingkat mortalita dan tingkat suku bunga. Premi netto untuk asuransi jiwa dwiguna dimana tertanggung berusia $x$ tahun, lama masa pertanggungan $n$ tahun dan pembayaran premi di awal tahun selama $m$ tahun, dinyatakan dengan:

$$
\begin{aligned}
{ }_{m} P_{x: n} & =\frac{A_{x: n}}{\ddot{a}_{x: m}} \\
& =\frac{\left[\left(\sum_{k=0}^{n-1} v^{k+1}{ }_{k} p_{x} q_{x+k}\right)+v^{n}{ }_{n} p_{x}\right]}{\sum_{k=0}^{m-1} v^{k}{ }_{k} p_{x}}
\end{aligned}
$$

Premi bruto adalah premi yang terdiri dari premi netto ditambah dengan biaya (loading) [6]. Biayabiaya loading ini adalah biaya penutupan polis baru $\left(a^{\prime}\right)$, biaya komisi agen setiap pengumpulan premi $(\beta)$, biaya pemeliharaan premi selama masa pembayaran $(\gamma)$, dan biaya pemeliharan premi setelah masa pembayaran $\left(\gamma^{\prime}\right)$. Premi bruto asuransi jiwa dwiguna untuk seorang yang berusia $x$, lama masa pertanggungan $n$ tahun, dan lama masa pembayaran $m$ tahun, dinyatakan dengan:

$$
{ }_{m} P_{x: n}^{*}=\frac{1}{1-\beta}\left({ }_{m} P_{x: n}+\frac{a^{\prime}}{\ddot{a}_{x: m}}+\gamma+\gamma^{\prime} \frac{\ddot{a}_{x: n}-\ddot{a}_{x: m}}{\ddot{a}_{x: m}}\right)
$$

\section{CADANGAN PREMI ASURANSI}

Iuran atau premi yang diterima perusahaan tidak hanya menjadi profit perusahaan tetapi sebagian juga merupakan kewajiban perusahaan di masa mendatang. Sebagian dari premi harus dicadangkan perusahaan sebagai cadangan premi sehingga bila di masa yang akan datang terjadi klaim, maka perusahaan tidak kesulitan membayarnya. Cadangan dalam dunia perusahaan biasanya diartikan sebagai suatu dana yang disisihkan untuk digunakan dalam keadaan darurat [7]. Perhitungan cadangan premi dapat dilakukan diantaranya menggunakan metode prospektif. Metode cadangan prospektif adalah perhitungan cadangan yang berorientasi pada pengeluaran diwaktu yang akan datang. Perhitungan cadangan berdasarkan nilai sekarang dari semua pengeluaran di waktu yang akan datang, dikurangi dengan nilai sekarang total pendapatan diwaktu yang akan datang untuk setiap pemegang polis [1]. Rumus cadangan premi pada tahun ke- $t$, untuk premi asuransi jiwa dwiguna dimana tertanggung berusia $x$, lama masa pertanggungan asuransi $n$ tahun dan pembayaran premi di awal tahun selama $m$ tahun, dengan metode prospektif yaitu:

$$
{ }_{t}^{m} V_{x: n}=A_{x+t: \overline{n-t} \mid}-{ }_{m} P_{x: n} \ddot{a}_{x+t: \overline{m-t}}
$$

\section{CADANGAN FULL PRELIMINARY TERM}

Cadangan full preliminary term merupakan perluasan dari cadangan zillmer dengan asumsi dimana polis yang berlaku untuk 1 tahun saja. Jadi, premi tahun pertama hanya cukup untuk menutupi biaya loading tahun pertama saha atau dengan kata lain cadangan tahun pertama sama dengan nol [8]. Rumus 
cadangan zillmer untuk asuransi jiwa dwiguna dimana tertanggung berusia $x$ tahun, lama masa pertanggungan $n$ tahun dan pembayaran premi di awal tahun selama $m$ tahun, [7] yaitu:

$$
{ }_{t}^{m} V_{x: n]}^{(Z)}=A_{x+t: \overline{n-t} \mid}-\left({ }_{m} P_{x: n}+\frac{a}{\ddot{a}_{x: n}}\right) \ddot{a}_{x+t: \overline{m-t}}
$$

Nilai $a$ didefinisikan sebagai tingkat zillmer atau rate zillmer. Pada umumnya dihindarkan adanya besar cadangan yang negatif [1]. Maka pada tahun pertama $(t=1)$, jika besar cadangan zillmer diasumsikan 0, dengan menggunakan Persamaan (2) diperoleh:

$$
0=A_{x+1: \overline{n-1}}-\left({ }_{m} P_{x: n}+\frac{a}{\ddot{a}_{x: n}}\right) \ddot{a}_{x+1: \overline{m-1}}
$$

Sehingga dapat dicari nilai $a$, yaitu:

$$
a=\left({ }_{m-1} P_{x+1: \overline{n-1}}-{ }_{m} P_{x: n}\right) \ddot{a}_{x: n}
$$

dengan mensubstitusikan Persamaan (2) ke Persamaan (3), diperoleh:

$$
{ }_{1}^{m} V_{x: n}^{(Z)}=A_{x+t: \overline{n-t}}-\left({ }_{m} P_{x: n}+\frac{\left({ }_{m-1} P_{x+1: \overline{n-1}}-{ }_{m} P_{x: n}\right) \ddot{a}_{x: n}}{\ddot{a}_{x: n}}\right) \ddot{a}_{x+t: \overline{m-t}}
$$

Rumus cadangan full preliminary term untuk asuransi jiwa dwiguna dimana tertanggung berusia $x$ tahun, masa pertanggungan $n$ tahun dan pembayaran premi di awal tahun selama $m$ tahun, [8] yaitu:

$$
{ }_{t}^{m} V_{x: n]}^{(F)}=A_{x+t: \overline{n-t} \mid}-{ }_{m-1} P_{x+1: \overline{n-1}} \ddot{a}_{x+t: \overline{m-t} \mid}
$$

\section{CADANGAN PREMIUM SUFFICIENCY}

Metode Cadangan premium sufficiency adalah metode perhitungan cadangan premi asuransi berdasarkan asumsi premi bruto. Cadangan premi asuransi dengan metode premium sufficiency dilakukan dengan modifikasi dimana perhitungan nilai sekarang pembayaran waktu yang akan datang akan ditambah dengan biaya manajemen Biaya managemen yaitu biaya komisi agen setiap pengumpulan premi $(\beta)$, biaya emeliharaan premi selama masa pembayaran $(\gamma)$, dan biaya pemeliharaan premi setelah masa pembayaran sampai habis masa pertanggungan $\left(\gamma^{\prime}\right)$.

Sehingga nilai sekarang pembayaran waktu yang akan datang untuk metode premium sufficiency berdasarkan metode prospektif menjadi, [8]:

$$
A_{x+t \overline{n-t} \mid}^{(p s)}=A_{x+t: \overline{n-t}}+\beta_{m} P_{x: n}^{*} \ddot{a}_{x+t: \overline{m-t}}+\gamma \ddot{a}_{x+t: \overline{m-t}}+\gamma^{\prime}\left(\ddot{a}_{x+t: \overline{n-t}}-\ddot{a}_{x+t: \overline{m-t}}\right) .
$$

Nilai sekarang penerimaan di waktu yang akan datang, premi yang digunakan juga premi kotor $P_{x: n}^{*}$. Sehingga nilai sekarang dari penerimaan yang akan datang untuk metode premium sufficiency diperoleh, [8]:

$$
P^{(\alpha)}={ }_{m} P_{x: n}^{*} \ddot{a}_{x+t: \overline{m-t} \mid}
$$

Sehingga berdasarkan Persamaan (4) dan Persamaan (5) yang dimodifikasi terhadap Persamaan (1) diperoleh cadangan premium sufficiency. Rumus cadangan premium sufficiency untuk asuransi jiwa dwiguna dimana tertanggung berusia $x$ tahun, lama masa pertanggungan $n$ tahun dan pembayaran premi di awal tahun selama $m$ tahun [7] diperoleh:

$$
{ }_{t}^{m} V_{x: n}^{(p s)}=A_{x+t: \overline{n-t} \mid}-\left({ }_{m} P_{x: \bar{n} \mid}+\frac{a^{\prime}}{\ddot{a}_{x: m}}\right) \ddot{a}_{x+t: \overline{m-t}}+\gamma^{\prime}\left(\ddot{a}_{x+t: \bar{n}-t \mid}-\frac{\ddot{a}_{x: \bar{n}}}{\ddot{a}_{x: m}} \ddot{a}_{x+t: \bar{m}-t}\right)
$$


Bersadarkan Persamaan (6), diperoleh informasi bahwa pada cadangan premi asuransi dengan metode premium sufficiency hanya biaya penutupan baru, $a^{\prime}$ dan biaya pemeliharaan premi setelah masa pertanggungan $\left(\gamma^{\prime}\right)$ yang mempengaruhi perhitungan nilai cadangan.

\section{APLIKASI NUMERIK}

Pada penelitian ini akan diberikan studi kasus sebagai simulasi perhitungan cadangan premi asuransi untuk produk asuransi jiwa dwiguna dengan program yang akan digunakan adalah Microsoft Excel. Contoh kasus, seorang pria yang berusia 30 tahun hendak mengikuti asuransi jiwa. Jenis asuransi jiwa yang hendak dipilih adalah asuransi jiwa dwiguna dengan masa pertanggungan 25 tahun. Pembayaran premi dilakukan setiap awal periode. Besar santunan yang akan diterima ahli waris adalah Rp150.000.000 dengan tingkat suku bunga yang digunakan adalah 3\%.

Perusahaan asuransi harus bijak dalam mengelola premi yang dibayarkan tertanggung. Premi selain untuk dikembalikan dalam bentuk santunan atau manfaat, premi juga digunakan untuk biaya operasional perusahaan, yaitu biaya penutupan baru sebesar $2,5 \%$ dari santunan dan biaya pengumpulan premi setelah masa pembayaran sebesar $0,13 \%$ dari santunan.

Kemudian dihitung besarnya nilai cadangan dengan menggunakan kedua metode. Hasil dari perhitungan terdapat pada Tabel 1. Metode cadangan premi full preliminary term dan premium sufficiency pada akhir masa pertanggungan memberikan cadangan yang berjumlah sebesar nilai pertanggungan. Hal ini dapat diartikan bahwa saat masa pertanggungan asuransi jiwa dwiguna berakhir, pihak asuransi telah siap untuk memberikan santunan sebesar yang dijanjikan kepada tertanggung. Nilai cadangan full preliminary term lebih murah dibandingkan dengan nilai cadangan premium sufficiency. Hal ini dikarenakan premi pada tahun pertama pada full preliminary digunakan untuk menutupi biaya loading sehingga nilai cadangan lebih murah.

Tabel 1 Nilai Cadangan Premi Menggunakan Metode Full Preliminary Term dan Premium Sufficiency

\begin{tabular}{|c|c|c|}
\hline $\mathbf{t}$ & ${ }^{m}{ }_{t}^{m} V_{x: n}^{(F)}$ & ${ }^{m}{ }_{t}^{m} V_{x: n}^{(P s)}$ \\
\hline 1 & $\mathrm{Rp}$ & 380.933 \\
\hline 2 & $\mathrm{Rp} \quad 4.263 .410$ & $\mathrm{Rp} \quad 4.633 .210$ \\
\hline 3 & Rp $\quad 8.653 .993$ & $\mathrm{Rp} \quad 9.012 .330$ \\
\hline $\bar{\vdots}$ & $\vdots$ & $\frac{\square}{\vdots}$ \\
\hline 23 & Rp 129.023.972 & Rp 129.067.356 \\
\hline 24 & Rp 137.173.948 & Rp 137.196.138 \\
\hline 25 & Rp 150.000.000 & Rp 150.000.000 \\
\hline
\end{tabular}

\section{CADANGAN PREMI SUKU BUNGA BERVARIASI}

Berdasarkan studi kasus dilakukan perhitungan dengan menambahkan tingkat suku bunga yang berbeda, diperoleh hasil nilai cadangan premi metode full preliminary term dan premium sufficiency dengan suku bunga 1\%-6\% ditampilkan pada Tabel 2 dan Tabel 3.

Berdasarkan Tabel 2 menunjukan bahwa nilai cadangan full preliminary term pada tahun pertama bernilai 0 karena premi pada tahun pertama digunakan untuk menutupi biaya loading. Semakin besar tingkat suku bunga bebas risiko, maka semakin besar nilai cadangan premi juga semakin murah. Hal ini karena tingkat suku bunga bebas risiko merupakan variabel dari fungsi diskonto. Semakin besar tingkat suku bunga bebas risiko, maka semakin kecil nilai dari fungsi diskonto. 
Tabel 2 Nilai Cadangan Premi Full Preliminary Term dengan Suku Bunga Bervariasi

\begin{tabular}{|c|c|c|c|r|r|r|}
\hline $\mathbf{t}$ & $\boldsymbol{i}=\mathbf{1 \%}$ & $\boldsymbol{i}=\mathbf{2 \%}$ & $\boldsymbol{i}=\mathbf{3 \%}$ & $\boldsymbol{i}=\mathbf{4 \%}$ & $\boldsymbol{i}=\mathbf{5 \%}$ & $\boldsymbol{i}=\mathbf{6 \%}$ \\
\hline 1 & $\mathrm{Rp} 0$ & $\mathrm{Rp} 0$ & $\mathrm{Rp} 0$ & $\mathrm{Rp} 0$ & $\mathrm{Rp} 0$ & $\mathrm{Rp} 0$ \\
\hline 2 & $\mathrm{Rp} 5.522 .771$ & $\mathrm{Rp} 4.859 .547$ & $\mathrm{Rp} 4.263 .410$ & $\mathrm{Rp} 3.730 .149$ & $\mathrm{Rp} 3.255 .333$ & $\mathrm{Rp} 2.834 .407$ \\
\hline 3 & $\mathrm{Rp} 11.101 .066$ & $\mathrm{Rp} 9.816 .045$ & $\mathrm{Rp} 8.653 .993$ & $\mathrm{Rp} 7.608 .335$ & $\mathrm{Rp} 6.671 .865$ & $\mathrm{Rp5} .836 .955$ \\
\hline$\vdots$ & $\vdots$ & $\vdots$ & $\vdots$ & $\vdots$ & $\vdots$ & $\vdots$ \\
\hline 23 & $\mathrm{Rp} 134.557 .611$ & $\mathrm{Rp} 131.794 .526$ & $\mathrm{Rp} 129.023 .792$ & $\mathrm{Rp} 126.252 .680$ & $\mathrm{Rp} 123.488 .516$ & $\mathrm{Rp} 120.738 .480$ \\
\hline 24 & $\mathrm{Rp} 141.474 .702$ & $\mathrm{Rp} 139.322 .364$ & $\mathrm{Rp} 137.173 .948$ & $\mathrm{Rp} 135.032 .608$ & $\mathrm{Rp} 132.901 .619$ & $\mathrm{Rp} 130.784 .276$ \\
\hline 25 & $\mathrm{Rp} 150.000 .000$ & $\mathrm{Rp} 150.000 .000$ & $\mathrm{Rp} 150.000 .000$ & $\mathrm{Rp} 150.000 .000$ & $\mathrm{Rp} 150.000 .000$ & $\mathrm{Rp} 150.000 .000$ \\
\hline
\end{tabular}

Berdasarkan Tabel 3 nilai cadangan premium sufficiency dengan suku bunga bervariasi menunjukan bahwa semakin besar tingkat suku bunga bebas risiko, maka nilai cadangan premi juga semakin murah. Hal ini karena tingkat suku bunga bebas risiko merupakan variabel dari fungsi diskonto. Semakin besar tingkat suku bunga bebas risiko, maka semakin kecil nilai dari fungsi diskonto. Pada tahun pertama untuk suku bunga 4\%-6\% diperoleh bahwa nilai cadangan premi pada tahun pertama bernilai 0 , dikarenakan premi pada tahun pertama tidak cukup untuk untuk membiayai biaya loading (biaya penutupan baru dan biaya pemeliharaan setelah pembayaran premi). kesimpulan dapat juga ditambahkan prospek pengembangan dari hasil penelitian dan aplikasi lebih jauh yang menjadi prospek kajian berikutnya.

Tabel 3 Nilai Cadangan Premi Premium Sufficency dengan Suku Bunga Bervariasi

\begin{tabular}{|c|c|c|c|c|c|c|}
\hline $\boldsymbol{t}$ & $\boldsymbol{i}=\mathbf{1 \%}$ & $\boldsymbol{i}=\mathbf{2 \%}$ & $\boldsymbol{i}=\mathbf{3 \%}$ & $\boldsymbol{i}=\mathbf{4 \%}$ & $\boldsymbol{i}=\mathbf{5 \%}$ & \multicolumn{1}{c|}{$\boldsymbol{i = 6}$} \\
\hline 1 & $\mathrm{Rp} 1.658 .606$ & $\mathrm{Rp} 984.463$ & $\mathrm{Rp} 380.933$ & $\mathrm{Rp} 0$ & $\mathrm{Rp} 0$ & $\mathrm{Rp} 0$ \\
\hline 2 & $\mathrm{Rp} 7.119 .732$ & $\mathrm{Rp} 5.811 .515$ & $\mathrm{Rp} 4.633 .210$ & $\mathrm{Rp} 3.577 .655$ & $\mathrm{Rp} 2.636 .955$ & $\mathrm{Rp} 1.802 .726$ \\
\hline 3 & $\mathrm{Rp} 12.635 .762$ & $\mathrm{Rp} 10.734 .870$ & $\mathrm{Rp} 9.012 .330$ & $\mathrm{Rp} 7.460 .039$ & $\mathrm{Rp} 6.068 .571$ & $\mathrm{Rp} 4.827 .519$ \\
\hline$\vdots$ & $\vdots$ & $\vdots$ & $\vdots$ & $\vdots$ & $\vdots$ & $\vdots$ \\
\hline 23 & $\mathrm{Rp} 134.713 .662$ & $\mathrm{Rp} 131.896 .924$ & $\mathrm{Rp} 129.067 .356$ & $\mathrm{Rp} 126.233 .100$ & $\mathrm{Rp} 123.402 .378$ & $\mathrm{Rp} 120.583 .265$ \\
\hline 24 & $\mathrm{Rp} 141.553 .423$ & $\mathrm{Rp} 139.374 .271$ & $\mathrm{Rp} 137.196 .138$ & $\mathrm{Rp} 135.022 .587$ & $\mathrm{Rp} 132.857 .330$ & $\mathrm{Rp} 130.704 .103$ \\
\hline 25 & $\mathrm{Rp} 150.000 .000$ & $\mathrm{Rp} 150.000 .000$ & $\mathrm{Rp} 150.000 .000$ & $\mathrm{Rp} 150.000 .000$ & $\mathrm{Rp} 150.000 .000$ & $\mathrm{Rp} 150.000 .000$ \\
\hline
\end{tabular}

\section{PENUTUP}

Perusahaan asuransi dalam membayar uang santunan jika terjadi klaim oleh peserta asuransi jiwa dapat diperoleh dari cadangan perusahaan, dan salah satu metode yang digunakan adalah metode full preliminary term dan premium sufficiency. Kedua asuransi menggunakan biaya operasional dalam perhitungan nilai cadangan asuransinya. Metode full preliminary term menggunakan asumsi bahwa besarnya cadangan pada tahun pertama hanya cukup untuk biaya operasional akan menghabiskan seluruh cadangan pada tahun pertama. Metode premium sufficiency merupakan metode yang menggunakan premi bruto, dimana perhitungan nilai cadangannya menyertakan biaya penutupan baru dan biaya pemeliharaan premi setelah masa asuransi. Perhitungan menggunakan metode cadangan full preliminary term dan premium sufficiency diperoleh bahwa nilai cadangan full preliminary term lebih murah dibandingkan nilai cadangan premium sufficiency. Hal ini dikarenakan premi pada tahun pertama pada full preliminary term digunakan untuk menutupi biaya loading sehingga nilai cadangan lebih murah. Perhitungan dengan menggunakan suku bunga bervariasi, diperoleh bahwa nilai cadangan premi akan semakin murah seiring dengan bertambahnya tingkat suku bunga yang digunakan. 


\section{DAFTAR PUSTAKA}

[1]. Futami, T. Matematika Asuransi Jiwa Bagian I. Tokyo: Incorporated Foundation Oriental Life Insurance Cultural Development Center;1993.

[2]. Bowers, N. L., Geerber, H. U., Hickman, J. C., Jones, D. A., \& Nesbitt, C. J. Actuarial Mathematics. Schaumhurg: Society Of Actuaries;1997.

[3]. Sembiring, R.K. Buku Materi Pokok Asuransi I. Jakarta: Universitas Terbuka;1986a.

[4]. Kellison, S. Theory of Interest, Edisi ke-7. New York: Mc.Graw Hill;1991.

[5]. Achdijad, Didi. Prinsip-Prinsip Aktuaria pada Asuransi Jiwa. Jakarta: Gunadarma;1990.

[6]. Salim A. Abbas. Asuransi dan Manajeman Risiko. Jakarta: Grafindo Persada;2007.

[7]. Effendi, A.R. Matematika Aktuaria . Jakarta: Universitas Terbuka;2001

[8]. Futami, T. Matematika Asuransi Jiwa Bagian II. Tokyo: Incorporated Foundation Oriental Life Insurance Cultural Development Center;1994.

$\begin{array}{lll}\text { LIA AMELIA TARIGAS } & : & \begin{array}{l}\text { Jurusan Matematika FMIPA UNTAN, Pontianak } \\ \text { liaameliatarigas@ student.untan.ac.id }\end{array} \\ \text { NEVA SATYAHADEWI } & : & \begin{array}{l}\text { Jurusan Matematika FMIPA UNTAN, Pontianak } \\ \text { neva.satya@ @math.untan.ac.id }\end{array} \\ \text { HENDRA PERDANA } & : & \begin{array}{l}\text { Jurusan Matematika FMIPA UNTAN, Pontianak } \\ \text { hendra.perdana@math.untan.ac.id }\end{array}\end{array}$

